\title{
PENGARUH RELIGIUSITAS KELUARGA DAN JENIS SEKOLAH TERHADAP PERILAKU MORAL SISWA SMK DI KABUPATEN BANTUL
}

\author{
Oleh: Ani Rusmiyati \\ SMK Muhammadiyah I Bantul \\ Email: anirusmiyati78@gmail.com
}

\begin{abstract}
This study aims to determine the effect of the family religious habit and school types to the SMK (vocational school) students' moral behaviors in Bantul regency. This study was using the quantitative descriptive method. The subjects of the study were SMK students in Bantul. The data collection technique used a research scale, interview, data presentation and data verification. The data analysis technique was multiple regressions analysis. The result of this study shows that there is significant positive effect of family religious habit concerning students' moral behaviors. The higher the family religious habit, the better the students' moral behaviors level. On the contrary, the lower the family religious habit, the lower the students' moral behaviors level will be. There is a positive and significant effect of school types in relation to students' moral behaviors. Furthermore there is significant difference between students who study in the religious schools and those who do not. Students of religious schools tend to have higher moral behavior level. There is a significant and simultaneous effect of family religious habit and school types in relation to students' moral behavior. It indicates that religious environment at family and school may affect the students' moral behaviour. Keywords: family religious habit, school type, students' moral behavior
\end{abstract}

\section{PENDAHULUAN}

Dalam rentang tahun 2017, data di Kabupaten Bantul memperlihatkan kecederungan penurunan moral remaja. Hal ini ditunjukkan adanya perilaku amoral remaja seperti bentuk kegiatan remaja klitih yang saat sekarang menjadi keresahan masyarakat kabupaten Bantul, sekelompok pemuda ini mempunyai kegiatan berkumpul pada malam dijalan-jalan. Kelompok pemuda ini melakukan kejahatan dengan menghadang terhadap seorang sepeda motor untuk dimintai uang dan terkadang tidak segan-segan melukai korbannya. Hal ini dilakukan di sekitar jalan Imogiri dan Jalan Bantul (Kedaulatan Rakyat, 2017). Selanjutnya, fenomena remaja memperkosa Anak SMP bersama-sama di sekitar Pasar Telo Karangkajen (Bernas, 2017). Begitupun fenomena yang terjadi di Kabupaten Bantul, siswa SLTA terlibat tawuran antar sekolah, juga sering terjadi. Fenomena lain adanya rasia yang dilakukan aparat ternyata terdapat pelajar SLTA yang terjaring melakukan amoral yang berbentuk mesum di dalam warnet, hal ini terjadi di Kecamatan Sewon, Kabupaten Bantul (Kedaulatan Rakyat, 2017).

Fakta lain hasil survey Komisi Perlindungan Anak (KPA, 2008), menunjukkan bahwa perilaku penyimpangan remaja berupa pergaulan bebas $62,7 \%$ dilakukan oleh siswa SLTP dan SLTA menyatakan sudah melakukan seks pranikah sebesar $93,7 \%$ remaja pelajar menyatakan sudah pernah melakukan stimulasi digital sekas dan oral seks. 97\% kalangan remaja pernah nonton film porno, sedangkan $25 \%$ remaja pernah melakukan aborsi, hamil di luar nikah.

Berdasarkan fenomena perilaku remaja di atas, maka perlunya upaya dari kalangan pendidik maupun keluarga dalam membentuk religiusitas remaja. Lingkungan keluarga sangat berperan dalam membentuk religiusitas anaknya yang tumbuh remaja, sedangkan pihak sekolah lewat peraturan dan tata tertib seperti menganjurkan siswa untuk berpakaian secara sopan dan menutup aurot. Langkah ini telah di lakukan Pemerintah Kabupaten Bantul yang menganjurkan 
seluruh siswa SMA/SMK yang beargama Islam untuk memakai jilbab.

Tata tertib ini sebagai upaya membentuk siswa-siswi supaya berperilaku secara religiusitas. Perilaku siswa muslim harus mampu menunjukkan jati dirinya untuk berperilaku keagamaan yang sesuai syariah yang dituntutkan dengan cara melaksanakan rutinitas keagamaan di sekolah tidak hanya sekedar mematuhi peraturan. Tetapi kenyataan masih banyak siswa muslim yang belum mampu menerapkan akidah dan syariat Islam secara baik. Masih banyaknya siswa yang beragama Islam beluam melakukan ibadah secara rutin dan benar ketika ada di sekolah, masih relatif sedikit siswa yang melakukan ibadah di sekolah, seperti sholat sunnah, maupun sholat wajib di masjid sekolah (Bertens, 2007: 137).

Hasil observasi menunjukkan adanya perbedaan antara siswa yang berlatar belakang pendidikan umum dengan siswa berlatar belakang pendidikan agama dalam berperilaku religiusitas maupun moral siswa. Siswa yang sekolah di sekolah umum belum tentuk memliki perilaku moral yang rendah, sebaliknya siswa yang sekolah di sekolah agama belum tentut memiliki perilku moral yang tinggi. Moralitas siswa sangat ditentukan adanya norma dan nilai yang ada di lingkungan masayrakat dan keluarga. Persepsi masyarakat tentang baik dan buruk perilaku seorang remaja dapat dilihat berdasarkan norma dan nilai yang tercipta dalam lingkungan masyarakat dan kelauarga. Pendapat Bertens (2007: 137) menjelaskan bahwa nilai moral dapat dilihat dari perilaku yang dapat dipertanggungjawabkan sesuai dengan hati nuraini seseorang, mewajibkan, dan bersifat formal. Thalib (2010: 143) menjelaskan terdapat 3 tingkat pekembangan moralitass, 1) tingkat prakonvensional, yaitu tingkat perkembangan yang memilki ciri individu melekat pada aturan dan menghargai kepentingan orang lain untuk memenuhi kebutuhan pribadi. 2) tingkat konvensional, yaitu tingkat perkembangan perilaku yang memiliki ciri individu mengharapkan hidup terlihat baik oleh orang lain, serta menjaga sistem sosial yang berlangsung. 3) tingkat pascakonvensional, yaitu tingkat perkebangan perilaku yang memiliki ciri individu relatif menjunjung tinggi aturan dalam memihak kepentingan dan kesejahteraan bersama, serta individu mengikuti aturan yang sesuai dengan asas hukum universal. Perilaku yang baik dan pantas disebut dengan akhlak mahmudah yaitu perilaku manusia yang mulia.

Hakekat dari kelaurga adalah sebagai wadah yang digunakan ungtuk membentuk sifat-sifat dari anggota kelaurga tersebut. Anggota kelaurga dalam hal ini adalah anakanak yang masih dalam bimbingan dan tanggungjawab orangtua. Dengan demkian orantua merupakan pembentuk pribadi anak dalam perilaku selanjutnya. Memberikan pendidikan anak secara benar dan baik untuk menjadikan keluarga yang religius berarti menumbuhkembangkan moral pada anak secara wajar. Mengelola potensi anak secara wajar dengan memenuhi kebutuhan baik jasmani maupun rokhaninya. Dalam rangka meningkatkan moral anak dapat dilakukan melalui pengembangan dan pembinan intelektual, perasaan dan budi pekerti. Usahausaha pengembangan dan pembinana moral remaja/anak harus didukung orang tua. Pembentuk akhlak anak tidak secara instan tetapi harus dilakukan sedini mungkin dan melalui proses panjang sehingga kebiasaan anak dalam berperilaku moral yang baik akan tertanam. Lingkungan masyarakat tempat bergaul remaja sangat berpengaruh terhadap pembentukan moral remaja, seperti lingkungan masyarakat, keluarga sangat membentuk perilaku anak selanjutnya.

Selain religiusitas keluarga faktor penting perlu diperhatikan yang dapat mempengaruhi perilaku moral siswa adalah latar belakang pendidikan atau jenis pendidikan formal yang ditempuh siswa, Jenis pendidikan formal siswa akan menentukan langkah selanjutnya siswa dalam berperilaku. 
Hasil observasi di dua sekolah formal yaitu SMK Negeri dan SMK Muhammadiyah, menunjukkan perbedaan moral siswanya. Dalam penelitian ini lebih spesifik ke objek yang beragama Islam yang diwakili SMK Negeri dan SMK Muhammdiyah Kabupaten Bantul. Hal ini diplih sebagai sampel karena mempunyai karakteristik yang sama, tata tertib dan aturn yang diterapkan juga sama. Kedua sekolah tersebut mewakili latar belakang pendidikan umum dan latar belakang pendidikan agama.

\section{METODE PENELITIAN}

Jenis penelitian dalam penelitian ini adalah deskriptif model korelasional. Populasi dalam penelitian ini yaitu seluruh siswa SMK Negeri 1 Pundong kelas XI berjumlah 8 kelas dan 262 siswa, siswa SMK Muhammadiyah 1 Bantul yang berjumlah 12 kelas dan 394 siswa. Sampel penelitian adalah siswa kelas XI SMK Negeri 1 Pundong yang beragama Islam berjumlah 66 dan siswa kelas XI SMK Muhammadiyah 1 Bantul sejumlah 66. Teknik pengumpulan data dengan kuesioner, pertanyaan terbuka dan observasi. Uji kualitas data menggunakan uji validitas, reliabilitas dan uji asumsi klasik. Rancangan Analisis menggunakan uji kualitatif dan kuantitatif yaitu regresi linier berganda.

\section{HASIL PENELITIAN}

Tabel 1. Deskripsi data hasil penelitian $(\mathrm{N}=132)$

\begin{tabular}{|c|c|c|c|c|c|c|c|c|}
\hline \multirow{3}{*}{ Variabel } & \multicolumn{4}{|c|}{ Data Hipotetik } & \multicolumn{4}{|c|}{ Data Empirik } \\
\hline & \multicolumn{2}{|c|}{ Skor } & \multirow{2}{*}{ Mean } & \multirow{2}{*}{ SD } & \multicolumn{2}{|c|}{ Skor } & \multirow{2}{*}{ Mean } & \multirow{2}{*}{ SD } \\
\hline & Max & Min & & & $\operatorname{Max}$ & $\min$ & & \\
\hline Religiusitas Keluarga & 112 & 28 & 70 & 14 & 104 & 71 & 92,20 & 5,91 \\
\hline Perilaku Moral Siswa & 76 & 19 & 47,5 & 9,5 & 72 & 45 & 62,23 & 4,35 \\
\hline
\end{tabular}

\section{Variabel Religiusitas Keluarga}

Berikutnya, akan diklasifikasikan ke dalam tiga kategori masing-masing tinggi, sedang, rendah, seperti ditunjukan Tabel 2. Tabel 2. Kategorisasi skor skala Religiusitas Keluarga

\begin{tabular}{|c|c|c|c|c|}
\hline No Kategori & Rumus & Skor & $\mathrm{Jml}$ & $\%$ \\
\hline 1. Rendah & $\begin{array}{c}(\mu-3 \sigma) \leq \mathrm{x} \\
<(\mu-1 \sigma)\end{array}$ & $\begin{array}{c}28 \leq x< \\
56\end{array}$ & 0 & 0 \\
\hline Sedang & $\begin{array}{c}(\mu-1 \sigma) \leq x \\
<(\mu+1 \sigma)\end{array}$ & $\begin{array}{c}56 \leq \mathrm{x}< \\
84 \\
\end{array}$ & 10 & 7,58 \\
\hline \multirow[t]{2}{*}{ 3. $\quad$ Tinggi } & $\begin{array}{c}(\mu+1 \sigma) \leq x \\
<(\mu+3 \sigma)\end{array}$ & $\begin{array}{c}84 \leq \mathrm{x}< \\
112\end{array}$ & 122 & 92,42 \\
\hline & Total & & 132 & 100 \\
\hline
\end{tabular}

Keterangan:

$\mu$ : Mean Hipotetik

$\sigma:$ Standar Deviasi

Berdasarkan kategorisasi tingkat perilaku moral siswa, dapat diketahui bahwa tidak ada subjek berada pada taraf kategori rendah, 10 subjek $(7,58 \%)$ berada pada kategori sedang, dan sisanya 122 subjek $(92,42 \%)$ berada pada kategori tinggi. Jadi dapat disimpulkan bahwa subjek penelitian ini cenderung memiliki tingkat religiusitas keluarga tinggi. Hal itu didukung oleh perbandingan antara mean hipotetik (70) maupun mean empiris $(62,23)$ termasuk dalam kategorisasi tinggi.

\section{Variabel Perilaku Moral Siswa}

Berikutnya, akan diklasifikasikan ke dalam tiga kategori masing-masing tinggi, sedang, rendah, seperti ditunjukan Tabel 3.

Tabel 3. Kategorisasi skor skala Perilaku Moral Siswa

\begin{tabular}{cccccc}
\hline No & Kategori & Rumus & Skor & Jml & $\%$ \\
\hline 1. & Rendah & $(\mu-3 \sigma) \leq \mathrm{x}$ & $19 \leq \mathrm{x}$ & 0 & 0 \\
& & $<(\mu-1 \sigma)$ & $<38$ \\
\hline 2. & Sedang & $(\mu-1 \sigma) \leq \mathrm{x}$ & $38 \leq \mathrm{x}$ & 8 & 6,06 \\
& & $<(\mu+1 \sigma)$ & $<57$ \\
\hline 3. & Tinggi & $(\mu+1 \sigma) \leq \mathrm{x}$ & $57 \leq \mathrm{x}$ & 124 & 93,94 \\
& & $<(\mu+3 \sigma)$ & $<76$ \\
\hline \multicolumn{7}{c}{ Total } & & 132 & 100 \\
\hline
\end{tabular}

Keterangan:

$\mu$ : Mean Hipotetik

$\sigma:$ Standar Deviasi 
Berdasarkan kategorisasi tingkat perilaku moral siswa, dapat diketahui bahwa tidak ada subjek berada pada taraf kategori rendah, 8 subjek $(6,06 \%)$ berada pada kategori sedang, dan sisanya 124 subjek $(93,94 \%)$ berada pada kategori tinggi. Jadi dapat disimpulkan bahwa subjek penelitian ini cenderung memiliki tingkat perilaku moral tinggi. Hal itu didukung oleh perbandingan antara mean hipotetik $(47,5)$ maupun mean empiris $(62,23)$ termasuk dalam kategorisasi tinggi.

\section{Pengujian Hipotesis}

\section{Uji Prasarat}

a. Uji Linieritas

Uji linearitas dilakukan dengan menggunakan test of linearity yang menunjukkan hubungan religiusitas keluarga terhadap perilaku moral siswa koefisien linieritas $(\mathrm{F})$ sebesar $=43,081$, sig $=0,000(\mathrm{p}$ $<0,05)$ artinya variabel religiusitas keluarga terhadap perilaku moral siswa memiliki hubungan yang linear.

b. Uji Normalitas

Tujuan uji multikolinieritas adalah untuk menguji apakah pada model regresi di atas ditemukan adanya korelasi yang kuat antar variabel independen atau bebas yaitu religiusitas keluarga dan jenis sekolah. Dari hasil olah data nilai VIF variabel religiusitas keluarga sebesar 1,071, dan variabel jenis sekolah sebesar 1,071, nilai tersebut $<5$, sehingga model regresi tersebut di atas tidak terjadi multikolinieritas sehingga model regresinya dapat digunakan.

\section{Analisis Regresi}

\section{Persamaan Regresi Berganda}

Berdasarkan olah data diperoleh persamaan regresi sebagai berikut: $\mathrm{Y}=$ $0,415 \mathrm{X}_{1}+0,177 \mathrm{X}_{2}$.Pada persamaan di atas ditunjukkan pengaruh variabel bebas yaitu religiusitas keluarga dan jenis sekolah terhadap variabel antara (terikat) yaitu perilaku moral siswa Koefisien beta masingmasing variabel bebas bernilai positif, hal ini menunjukkan bahwa variabel bebas (X) berpengaruh terhadap variabel terikan $(\mathrm{Y})$ secara positif, yaitu setiap kenaikan variabel bebas (X) akan diikuti kenaikkan variabel terikat $(\mathrm{Y})$.

\section{Uji t}

\section{Pengaruh Religiusitas keluarga dan Perilaku moral siswa}

Berdasarkan hasil olah data variabel religiusitas keluarga t-hitung lebih besar dari ttabel $(5,221>1,984)$ dengan probabilitas $(0,000)$ lebih kecil dari taraf signifikan 0,05 , dengan demikian dapat disimpulkan terdapat pengaruh positif dan signifikan variabel religiusitas keluarga terhadap perilaku moral siswa. Hal ini menunjukkan bahwa semakin tinggi religiusitas keluarga, semakin tinggi tingkat perilaku moral siswa, sebaliknya semakin rendah religiusitas keluarga, maka semakin rendah tingkat perilaku moral siswa.

\section{Pengaruh Jenis Sekolah dan Moral Siswa}

Berdasarkan hasil olah data variabel Jenis Sekolah t-hitung lebih besar dari t-tabel $(2,225>1,984)$ dengan probabilitas $(0,028)$ lebih kecil dari taraf signifikan 0,05, dengan demikian dapat disimpukan terdapat pengaruh positif dan signifikan antara Jenis Sekolah dengan perilaku moral siswa. Dengan kata lain ada perbedaan perilaku moral siswa yang signifikan antara siswa yang sekolah di sekolah agama dengan siswa yang sekolah non agama. Siswa yang sekolah di sekolah agama memiliki perilaku moral lebih tinggi jika dibandingkan dengan perilaku modal siswa yang sekolah di non agama.

\section{Uji F}

Berdasarkan hasil olah data diketahui nilai F-hitung sebesar 20,447, nilai signifikan sebesar 0,000. Sesuai jumlah observasi diketahu nilai F-tabel sebesar 2,70, sehingga disimpulkan bahwa F-hitung $>$ F-tabel dengan tingkat signifikan $0,000<0,05 \quad(\mathrm{p}<0,05)$, dengan demikian terdapat pengaruh religiusitas keluarga dan jenis sekolah secara simultan terhadap perilaku moral siswa.

\section{Koefisien Determinasi}

Dari perhitungan olah data diperoleh nilai Adjusted $\mathrm{R}^{2}=0,229$ atau 22,9\%, hal ini menunjukkan bahwa perilaku moral siswa 
dipengaruhi religiusitas keluarga dan Jenis Sekolah sebesar 22,9\%. Sedangkan sisanya sebesar $77,1 \%$ dipengaruhi faktor lain.

\section{PEMBAHASAN}

Hasil uji $t$ menunjukkan variabel religiusitas keluarga memiliki t-hitung lebih besar dari t-tabel $(5,221>1,984)$ dengan probabilitas $(0,000)$ lebih kecil dari taraf signifikan 0,05 , artinya ada hubungan positif dan signifikan anatra religiusitas keluarga dengan perilaku moral siswa Semakin tinggi religiusitas keluarga, semakin tinggi tingkat perilaku moral siswa, sebaliknya semakin rendah religiusitas keluarga, maka semakin rendah tingkat perilaku moral siswa. Diterimanya hipotesis yang diajukan oleh peneliti berarti mendukung hasil penelitian Wolfgang Jagodzinski (2009), yang menyatakan bahwa terdapat perbedaan yang signifikan antara keluarga yang memilki nilai religiusitas terhadap perilaku moral. Keluarga yang beragama lebih memliki perilaku moral yang baik, jika dibandingkan dengan kelauarga yang memliki rata-rata nilai agama rendah. Selain itu peneliti Ara Norenzayan. (2014) juga menyatakan bahwa keyakinan berpengaruh positif dan signifikan terhadap perilaku moral. Praktek Keagamaan berpenagruh positif dan signifikan terhadap perilaku moral.

Hasil penelitian di atas menudukung hasil penelitian deskriptif data variabel religusitas yang masuk kategori tinggi. Artinya apabila suatu keluarga memahami pengetahuan agama, keyakinan agama, pengalaman ritual agama, perilaku dan sikap sosial keagamaan yang diwujudkan dalam bentuk keyakinan (akidah) yang baik, pengalaman agama yang tinggi dan Praktek agama (syariah) yang baik, maka akan membentuk perilaku moral siswa yang baik. Sesuai pendapat Al- Mawari, (2002), tingkat pengetahuan agama seseorang dalam memahami agama dapat dilalui dengan aktivitas rasional empiris maupun tekstualnormatif. Proses memahami dan memberi makna terhadap agama akan mendorong praktek ritual keagamaan dalam kehidupan manusia, sehingga praktek ritual keagamaan merupakan realisasi dari adanya dorongan niat memahami dan memberikan makana terhadap realitas beragama manusia yang berpengaruh pada perilaku moral seseorang.

Hasil ini sesuai hasil wawancara dengan seorang guru yang menyatakan bahwa "siswa yang berasal dari kalangan keluarga yang religiusitas, biasanya siswa berperilaku disiplin, taat pada perintah guru, siswa lebih condong pendiam, selain itu siswa setiap ditanya keadaanya sering mengucapkan alkhamdulillah". Pendapat tersebut menunjukkan bahwa likungan keluarga yang religius mampu berdampak pada perilaku moral siswa. Perilaku yang positif di kelaurga akan dibawa ke dalam lingkungan sekolah. Keberagamaan atau religiusitas diwujudkan dalam berbagai sisi kehidupan manusia. Aktifitas beragama bukan hanya terjadi ketika seseorang melakukan aktifitas lain yang didorong oleh kekuatan supra natural. Bukan hanya berkaitan dengan aktifitas yang tak tampak dan terjadi dalam hati seseorang, karena itu keberagamaan seseorang akan meliputi berbagai dimensi seperti keyakinan (akidah) yang baik, pengalaman agama yang tinggi dan Praktek agama (syariah).

Hasil uji t menunjukkan variabel jenis sekolah memiliki nilai t-hitung 2,225, lebih besar dari nilai $t$ tabel sebensar 1,984, dengan p value 0,028 lebih kecil dari taraf signifikan 0,05 , dengan demikian dapat disimpukan ada hubungan positif dan signifikan antara Jenis Sekolah dengan perilaku moral siswa. Dengan kata lain ada perbedaan perilaku moral siswa yang signifikan antara siswa yang sekolah di sekolah agama dengan siswa yang sekolah non agama. Siswa yang sekolah di sekolah agama memiliki perilaku moral lebih tinggi jika dibandingkan dengan perilaku moral siswa yang sekolah di non agama. Hasil penelitian ini didukung hasil penelitian Nur Azizah (2010), menemukan hasil penelitian bahwa latar belakang pendidikan melmiliki perbedaan yang signifikan terhadap perilaku 
moral siswa. Pendidikan yang berlatar belakang agama lebih memeliki moral lebih baik dibandingkan yang berpendidikan umum. Relegiusitas memiliki peran penting yang tidak dapat dipisahkan dengan pengelolan manusia seutuhnya. Sesuai dengan tujuan pendidikan nasional yang meletakkan nilainailai agama sebagai pondasi moral siswa, sebab negara Indonesia merupakan negara yang beragama. Agama bagi bangsa Indonesia adalah modal dasar yang menjadi penggerak dalam kehidupan berbangsa. Agama telah mengatur hubungan manusia dengan Tuhannya, hubungan manusia dengan manusia, hubungan manusia dengan alam dan hubungan manusia dengan diri sendiri. Dengan demikian terjadilah keserasian dan keseimbangan dalam hidup manusia baik sebagai individu maupun sebagai anggota masyarakat. Untuk meningkatkan religiusitas di sekolah maka perlu dilakukan terobosan kegiatan yang mampu meningkatkan kreatifitas siswa seperti; kegiatan olimpiade.

Dari uji F diketahui bahwa nilai nilai Fhitung adalah 20,447. Dengan nilai signifikan sebesar 0,000, dan nilai F-tabel adalah 2,70. Dengan demikian dapat disimpulkan bahwa Fhitung $>$ F-tabel dengan tingkat signifikan $0,000<0,05 \quad(p<0,05)$, sehingga dapat disimpulkan bahwa ada hubungan religiusitas keluarga dan Jenis Sekolah secara simultan dengan perilaku moral siswa. Hal ini menunjukkan apabila religiusitas keluarga semakin baik dengan lingkungan sekolah beragama, maka akan mendorong siswa berperilaku moral yang baik pula. Lingkungan sekolah yang mendukung, dalam ini sekolah agama yang diiringi dengan lingkungan keluarga yang religius, maka akan berpengaruh pada anak untuk berperilaku moral yang baik. Perilaku moral siswa dipengaruhi religiusitas keluarga dan Jenis Sekolah sebesar $22,9 \%$. Sedangkan sisanya sebesar $77,1 \%$ dipengaruhi faktor lain.

\section{KESIMPULAN}

1. Ada pengaruh positif dan signifikan antara religiusitas keluarga terhadap perilaku moral siswa Semakin tinggi religiusitas keluarga, semakin tinggi tingkat perilaku moral siswa, sebaliknya semakin rendah religiusitas keluarga, maka semakin rendah tingkat perilaku moral siswa

2. Ada pengaruh positif dan signifikan antara Jenis Sekolah terhadap perilaku moral siswa. Dengan kata lain ada perbedaan perilaku moral siswa yang signifikan antara siswa yang sekolah di sekolah agama dengan siswa yang sekolah non agama. Siswa yang sekolah di sekolah agama memiliki perilaku moral lebih tinggi jika dibandingkan dengan perilaku modal siswa yang sekolah di non agama.

3. Ada pengaruh singnfikan antara religiusitas keluarga dan Jenis Sekolah secara simultan terhadap perilaku moral siswa. Hal ini menunjukkan apabila religiusitas keluarga semakin baik dengan lingkungan sekolah beragama, maka akan mendorong siswa berperilaku moral yang baik pula.

\section{DAFTAR PUSTAKA}

Ahmad Nawawi. (2010). "Pentingnya Pendidikan Nilai Moral Bagi Generasi Penerus" Jurnal, Jurusan PLB FIP Universitas Pendidikan Indonesia.

Ahmad Thontowi. Hakekat Religiusitas, dari: sumsel.kemenag.go.id, diakses tanggal 20 April 2017.

Al- Mawari. (2002). Ridho Mengatasi Sedih Dengan Depresi, Jakarta: Pustaka Belajar,

Allen, D.E. (1980). Social Psychology as ASocial Process. California: Wodworten Publishing Company.

Ancok, Djamaludin., Suroso, Fuat Nashori. (2008). Psikologi Islami.Yogyakarta. Pustaka. Pelajar.

Anshari, S.E. (1986). Wawasan Islam. Jakarta: PT Rajawali Press.

Arikunto, Suharsimi. (2010). Prosedur Penelitian Suatu Pendekatan Praktek, Jakarta. Rineka Cipta. 
Azizah, Nur. (2006). "Perilaku Moral dan Religiusitas Siswa Berlatar Belakang Pendidikan Umum dan Agama", Jurnal Psikologi. Volume 33, No. 2,

Carolyn Kisner Lynn Allen Colby. (2007). Therapeutic Exercise, Fifth Edition, (Philadelpia : F.A. Davis Company).

Cedric Hall dan Joanna Kidman. (2004). Teaching and Learning: Mapping the Contextual Influences. International Education Journal Vol 5, No 3.

Chaplin, J. P. (2001). Kamus Lengkap Psikologi. Terjemahan oleh Kartini dan Kartono. Jakarta: Raja Grafindo Perkasa.

Daradjat, Zakiah. (2000). Ilmu Pendidikan Islam, Jakarta: Bumi Aksara.

Fitri Fauziah \& Julianty Widuri. (2007). Psikologi Abnormal Klinis Dewasa. Universitas Indonesia (UI-Press): Jakarta.

Handayani, Nani. (2013). "Korelasi Antara Tingkat Religiusitas terhadap Perilaku Sosial Pekerja Malam di Executive Club Yogjakarta”, Jurnal Psikologi, UIN Sunan Kalijaga.

Hurlock, E.B. (1990). Perkembangan Anak. Alih Bahasa: Meitasari Tjandrasa dan Muslih Zarkasi. Jakarta: Erlangga.

Hurlock, E.B. (2009). Psikologi Perkembangan. Jakarta: Erlangga.

Jalaluddin. (2003). Psikologi Agama.Jakarta: Raja Grafindo Persada.

Jockson, P.W. (1998). Date The Moral life Of School. San Francisco: Jossey-Bass Publishers.
Kurtines, W.W \& Gerwitz, J.L. (1992). Moralitas, Perilaku Moral, dan Perkembangan Moral. Penerjemah: M.I. Soelaeman. Jakarta: UI Press.

Muhaimin. (2005). Pengembangan Kurikulum Pendidikan Agama Islam di sekolah, Madrasah, dan Perguruan Tinggi. Jakarta: PT Raja Grafindo Persada.

Nashori, Fuad. (2002). Agenda Psikologi Islami. Yogyakarta: Pustaka Pelajar. Hal. 86

Ni Putu Bintari, Nyoman Dantes, dan Made Sulastri. (2014). "Korelasi Konsep Diri Dan Sikap Religiusitas Terhadap Kecenderungan Perilaku Menyimpang Dikalangan Siswa Pada Kelas Xi Sma Negeri 4 Singaraja Tahun Ajaran 2013/2014”. e-journal Undiksa Jurusan Bimbingan Konseling Volume: 2 No 1

Nurjanah, Siti. (2014). "Pengaruh Tingkat Religiusitas Terhadap Perilaku Disiplin Remaja di MAN Sawit Boyolali", Jurnal, Fakultas Ilmu Tarbiyah dan Keguruan Universitas Islam Negeri Syarif Hidayatullah, Jakarta.

Purwanto, Ngalim. (2005). Psikologi Pendidikan. Bandung: PT Remaja Rosda Karya.

Rogers, D. (1977). The Psychology of Adolescence. Englewood Cliff, New Jersey: Prentice Hall.

Sugiyono. (2010). Metode Penelitian Kuantitatif Kualitatif dan RD. Bandung: Alfabeta.

Thouless, R.H. (2000). Pengantar Psikologi Agama. Penerjemah: Machnun Husein. Jakarta: PT Raja Grafindo Persada. 